\title{
Working Out What to Wear in \\ Papua New Guinea: The Politics \\ of Fashion in Stella
}

Ceridwen Spark

In August 20I2, I was browsing in the hotel shop at the Holiday Inn in Port Moresby when an attractive magazine entitled Stella caught my eye. It stood out from the Australian women's magazines next to it, partly because it had a Papua New Guinean woman on the cover. I became even more interested when I realized that the woman was Jennifer Baing-Waiko, a 34-year-old of mixed ethnic heritage who is involved in various agricultural projects with her father's people in Papua New Guinea's (PNG's) Markham Valley.

When I first saw Stella, I was involved in making a series of films about Papua New Guinean women leaders, and we had chosen Jennifer to be one of the subjects. She was something of a controversial choice. Some of those involved in the film project felt that Jennifer, as the daughter of a politician and a white New Zealander, would be seen by many Papua New Guineans as privileged and hard to relate to. I was thus intrigued to see Jennifer on a magazine and to learn more about how and who had got her there.

I soon discovered that the creative force behind Stella is Amanda Donigi, a 34-year-old Papua New Guinean woman and the magazine's founder and editor. In March 2013, I interviewed Donigi for this research (unless otherwise specified, all quotations from Donigi are from this interview, conducted on 2 March 20I3). Having completed her degree in editing and publishing and worked in the publishing industry in Port Moresby, Donigi was passionate about creating a magazine that she "would want to read." Tired of both the Western and Papua New Guinean media's depictions of Papua New Guinean women, Donigi determined to create this "thinking woman's magazine from Papua New Guinea for the Pacific" (Stella maga-

The Contemporary Pacific, Volume 27, Number I, 39-70

(C) 2015 by University of Hawai' $i$ Press 
zine website). Stella looks and feels different from any other locally produced magazine on sale in PNG or elsewhere in the Pacific. Eye-catching and glossy, it stands out on the shelves of shops in major hotels and other tourist destinations in Port Moresby. But as is evident from Donigi's decision to put Jennifer Baing-Waiko on the front cover, Stella's distinctive look is not the only thing that makes it different.

As with the majority of women's magazines, Stella presents images of women who look more glamorous than women tend to in everyday life. The difference in the case of Stella is that the women on these front covers and inside in the photo shoots are Papua New Guinean-but not as they are typically depicted. In this way, the magazine implicitly subverts expectations about what Papua New Guinean women "should" look like (modestly dressed and without make-up), be doing (gardening, cooking, or tending children) and where (in the village, house, or garden and local rather than international) (Spark 20I4a). Countering both local representations of women and the ways Papua New Guinean women tend to be depicted in the Australian and international press-namely, as victims of domestic violence-the magazine represents an important site for the reflection and creation of new Pacific femininities (for discussion, see Spark 20I4a). Its aesthetic, both inside and outside, is a crucial part of this refiguring.

In this article, I elaborate on my previous arguments about Stella by exploring how the representations of fashion in this magazine open up and encourage the celebration of versions of femininity hitherto marginalized in the Pacific. Drawing on a range of sources, I argue that Stella invites Papua New Guinean women to explore new versions of femininity based on forms of "power" and "freedom" that have typically been associated with women from "elsewhere." But it does so in a unique way. Reframing both the local and indigenous and presenting this as an aesthetic within the global discourse of fashion, the magazine sends an important and liberating message: that Pacific women can be culturally distinctive while participating in global trends. In this way, the social changes associated with globalization become "not . .. something that happens to people but rather, something that they themselves ... participate in ... through their own choices" (Cummings 20I3a, 383). Providing a context through which readers can push the boundaries of what it means to be a Papua New Guinean woman, the magazine presents images that invite readers to celebrate different versions of femininity than those that have tended to be valued in this context. As part of this, Stella encourages women to 
embrace their status as modern subjects with traditional roots. Through its front covers, regular section on secondhand clothing, and representations and promotion of local products and designs, Stella encapsulates and reflects contemporary Papua New Guinean women's blending of the local and the global, the modern and the traditional. As the title for the feature on model Theresa Sape Samuel states, educated Papua New Guinean women are living in "the age of options" (see figure I).

In order to write about the fashion in and aesthetics of Stella, I draw on a mixed methods approach. This entailed reading the magazine, including readers' letters as well as the articles, blogs, and social media commentary in PNG about what women are wearing. For the research, I also interviewed Stella editor Amanda Donigi and PNG-born, Melbourne-based blogger Pauline Vetuna. In addition, I surveyed and interviewed fifteen Papua New Guinean women readers of the magazine. In keeping with the magazine's readership, some of the research participants lived in Australia, while others were interviewed in the town of Goroka in the Eastern Highlands Province of PNG. Participants were aged between 2I and 35, with the average age being 28 years old. All but one of the interviewees are single, and only three of them have children. All but one have participated in tertiary education and were either studying or working at the time of interview. The research also draws on research conducted as part of other projects and over various field trips since 2007 (Spark 20IO, 20II, 20I3). This includes in-depth interviews and correspondence with young, educated Papua New Guinean women about their lives. With the exception of Amanda Donigi and Pauline Vetuna, both of whom have public profiles, I have used pseudonyms to refer to those who participated.

Before taking a closer look at the magazine, it is necessary to consider more about the context in which it has arisen. This includes a discussion of gender in PNG as well as consideration of the ways in which the clothes worn by educated modern women in PNG are interpreted as evidence of their transgressions, including their "betrayal" of proper gender roles and "cultural values." As Lissant Bolton has discussed in relation to the introduction of European-style clothing in Vanuatu, such interpretations confirm that in Melanesia, as elsewhere, clothing is read as signifying both status and gender (2003, I I9-I39). Women's donning of modern clothing is construed in PNG as an indication that they are seeking to enact roles that have "thus far been gendered male" (Bolton 2003, I37). At the heart of anxiety about what women are wearing in PNG are concerns about status, masculine privilege, and the right to control women. These concerns 


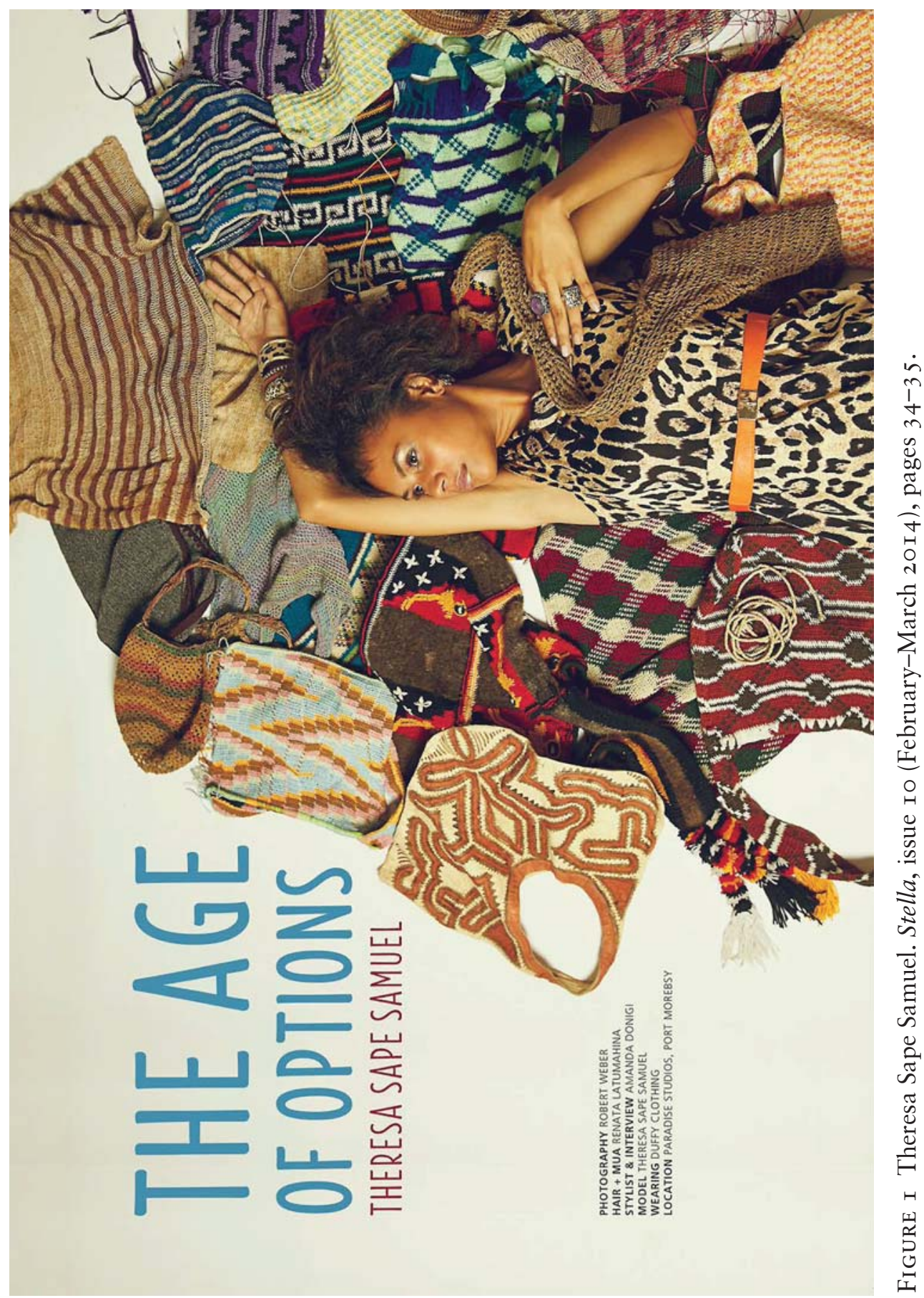


are also intricately interwoven with "class"-based jealousies for, as I have noted elsewhere (Spark 20I4b), the idea that education confers privilege is widespread in PNG, despite the limitations of such assumptions in a context in which only one in eight school leavers gains employment.

\section{Modern Women in Urban Papua New Guinea}

Twenty-six years ago, discussing the impact of education and change on the Simbu people of Papua New Guinea, anthropologist Paula Brown wrote: "traditional gender roles do change. Perhaps a new generation of educated, urbanized ... women will participate in national affairs and politics" (I988, I37). In 20 I 2, three women were elected to Parliament in Papua New Guinea. The excitement surrounding this outcome was widely interpreted as an indicator of the kind of social change Brown anticipated. And yet, as has been documented in countless reports and research publications, the Pacific region continues to be one of the most inequitable in the world in terms of gender.

Despite the plethora of research on gender and the many projects designed to improve their status, Papua New Guinean women continue to be disadvantaged and marginalized in social, economic, and political spheres. Strong traditions of male dominance and privilege persist in most parts of the country. Moreover, in the contemporary setting, gender inequity coexists with class difference, and, in this schema, educated women such as those described in this article are portrayed as "inauthentic and non-representative" (Macintyre 2000, I 53; see also Jolly 2005). The notion that there is an authentic version of womanhood-a convenient way to undermine women's claims to power (Zimmer-Tamakoshi I993, I997) - also serves to fuel antagonism toward educated women among those who feel themselves to be disenfranchised from power and opportunity (see also Gewertz and Errington 1999; Wardlow 2005). This also explains why women with tertiary degrees and employment in the professional workforce are readily construed as scapegoats and derided in public settings. When "middle-class" women travel or walk to work or go shopping in the markets of Goroka or Port Moresby, their clothing marks their privilege and difference from the majority of Papua New Guineans. There is anecdotal evidence to suggest that this difference makes them particularly vulnerable to various forms of assault (see Spark 20I4b).

Despite many changes in women's roles since PNG independence in I975, on an everyday basis, many if not most Papua New Guinean women 
continue to wear loose-fitting skirts with a meri blouse or loose T-shirt. Meri blouses were introduced to Papua New Guinean women by missionaries and, like the island dress in Vanuatu or the vinivo in Fiji, they have been a standard item for most women around the country since. Indeed, as Chloe Colchester wrote: "the extended influence of Victorian mission to the Pacific is most evident ... in Pacific women's contemporary dress. Even today, foreign visitors are often surprised to discover that Pacific women's 'traditional dress' consists of all-concealing tent-like cotton pinafores" (2003a, I). Some meri blouses come to the knee, others are hip length, but both styles are designed to disguise a woman's shape and convey her modesty. Though meri blouses are still popular attire, including among young women, an increasing number of women and particularly in PNG's capital, Port Moresby, are wearing clothes as likely to be seen on women in other parts of the world. To some extent, these changes are also evident in rural areas, and an increasing number of women are wearing jeans and T-shirts in various parts of the country. Nevertheless, it is fair to say that PNG's towns and cities, and Port Moresby in particular, are seen as sites where young women are likely to make more varied and adventurous sartorial choices than they tend to in rural areas.

An important factor influencing women's outfits is the ease of access to, and affordability of, secondhand clothing sent from Western countries and sold in the secondhand clothing stores in PNG's towns. Shopping for secondhand clothes is a popular pastime among those with even a small amount of disposable income. Consequently, it is common to see women of various income levels, backgrounds, and ages wearing clothes worn only briefly by their fashionable counterparts in Australia and New Zealand (where most of the clothing originates before being shipped to PNG in large containers).

On a surface level, the changes in women's outfits may be explained simply through reference to "globalization" (Linnekin 2004; Weinbaum and others 2008). The danger of this explanation is that it can suggest passive consumerism or mere replication. While fashion may be thought of as global, it is always reworked in specific locales (Roberts 2008; Addo 2009; Colchester 2003 b). In the case of PNG, this reworking involves Papua New Guinean women's creative engagement with fashions in ways that incorporate locally made and traditional pieces, designs, and influences. It is important to note that such reworking involves a degree of courage, for dressing in ways that tend to be associated with "outside" influences continues to present risks in this context. 
In PNG, it is common for women who deviate from the unofficial uniform of loose skirts and meri blouses to be confronted with harassment, ridicule, and violence. During the course of my research with young educated women, many have implicitly linked their clothing with their status as targets of abuse. This is evident, for example, in an e-mail Vera sent to me about security issues. It demonstrates that women who display autonomy through their clothing, behavior, or financial independence are perceived as "asking for it":

In Port Moresby, I have had experiences ranging from incidents of bag-thefts and attempted pick pocketing in buses as well as waiting at bus stop areas or walking from bus stop areas. I was once held-up at knife-point by a group of boys demanding for my bag and money, and have been on the receiving end of uncalled for heckling, jeering and name-calling either because of the way I was dressed or just because I was a female walking past a group of guys. I deal with this by ignoring all and walking by as though I have heard nothing. I have witnessed women and girls dressed differently to ones in meri blouses and lap lap or oversized outfits getting heckled and insulted, sometimes abused verbally in Port Moresby.

A recent discussion on PNG Facebook also highlighted local perspectives on the relationship between rape and the way women dress. For instance, one male contributor wrote: "Rape happens bcoz of one or more factors $\mathrm{n}$ dress code is undeniably ONE factor. ... wrong dressing at da wrong place" (28 Feb 20I4). Another contributor went further, explicitly reminding women of their "responsibilities," as in the following example: "Ladies its [sic] common sense, you don't need an angel or God to come down from heaven and tell you. Just to be on the safe side, please do the right thing" (28 Feb 20I4). Such allocations of responsibility shift discussion away from those who perpetrate sexual violence, revealing a crucial link between perceptions about what women wear and the idea that they are "asking for trouble."

In PNG, it can be intensely challenging to make countercultural choices about clothing. Consequently, most of the women I have spoken with for my research expressed dilemmas about "what to wear." Sue, a 28 -yearold researcher now living in Goroka after six years of study in Australia, described the challenges:

My dress sense caused a lot of problems when I first came here. I just thought what I was wearing was just really chicken ... not so. Yeah, it became a safety issue and I had to be told by one of my male colleagues.... I remember Henry 
warning me, not warning me as in telling me off but saying "for your own safety maybe cover up a bit more" ... and then I found myself going to a total extreme of covering up because he brought up this security, safety issue and said, “you know, you don't want to attract attention that might be . . . that might compromise your safety." So I took that on board and then dressed, or went almost over the top, covered up totally. . . . I didn't really know what I should wear and I wished that I was back in school and there was a uniform. It was such a dilemma every morning to wake up and work out what to wear.

As Maggie Cummings has noted, modern clothing has multiple meanings (2008). Discussing "the trouble with trousers" in Vanuatu, she wrote: "The issue at stake is not that trousers lack meaning; it is that when worn by young, urban women, trousers are associated with sexual availability, with women's increasing access to education, money, and mobility, and with rights that young ... women feel they should share with women from elsewhere" (Cummings 2008, I46). It is this proliferation of meaning that underpins Sue's uncertainty about what to wear. Her frustrationexpressed in her wish that "there was a uniform"-indicates why many women in PNG continue to wear the unofficial uniform of meri blouses and loose skirts or lap-laps. Young women can pay a high price for maintaining an identity constructed through reference to global discourses and fashions.

\section{The Politics of Fashion}

The above discussion demonstrates the intensely political nature of what women wear. Beyond PNG, feminists continue to discuss the links between women's clothing and the development and expression of feminism. These discussions often center on questions of whether "feminine style is compatible with feminist substance" (Jacobsen 20I0, I79) and whether investments in appearance represent an assertion of power or evidence of subjection to it. When feminists in Western liberal democracies debate these issues, they tend to assume that young women of today benefit from the political work of their feminist forebears, those who contested women's marginal status and fought for equality in relationships, the workplace, and the public domain. In this schema, even when today's women reject the label "feminist," the freedoms they experience are seen as an inheritance derived from the feminists who paved the way for the present generations of young women. Such freedoms include a young woman's being able to "produce 'speech acts' with her choice of clothing" (Duits and van 
Zoonen 2006, quoted in Gill 2007, 69) and the possibility that women who wear less rather than more are not "duped by patriarchy" (see Budgeon and Currie 1995, I73) but are empowered agents who are actively transforming gender norms and ideas about female sexuality.

In PNG, it is not possible to assume that young women's choices are constructed through reference to past feminisms, whether as a rejection or an embrace of these ideas. My interviews with young women in PNG have yielded an ambivalent response on the subject of feminism, with many considering the term to represent a more "radical" position than one with which they would wish to be associated. For instance, Jacqui (age 25) said she thought of the term "feminist" as describing "crazy women" with radical ideas, but on visiting Canada she saw that the term was being used more broadly. She said that now she thinks of a feminist as "somebody who is concerned about the rights of others and somebody who is willing to do something to address the problem that's there." The idea that feminism involved being separatist and radical was also articulated by Grace:

Maybe also the other thing is they [PNG women] don't really understand what it means, and the other thing is by being seen as a feminist in Papua New Guinea in general they feel like the men see that they are going up against them, and that's not what they want to do, they don't want to see that they're going against men but they're working with men. So "feminist" is only used for the women who never want to marry, they just are tomboys. Like, they're against men, they're radical.

On the basis of these interviews (though they are limited in number), I would suggest that while young women in PNG might be unwilling to describe themselves as feminist because of concerns about how they would be perceived, they are nevertheless in sympathy with many of feminism's goals. After all, the majority of young educated women have grown up in an environment in which gender workshops and "trainings" are commonplace. The subject of how young women see feminism-including further discussion of the extent to which they may think differently from older generations of PNG women, many of whom saw Western liberal feminism as inappropriate in the Pacific-bears further investigation and is the subject of an article I am currently writing about emerging women leaders in the Pacific.

While only an absolute minority of PNG women describe themselves as "feminists," an increasing number of women are wearing clothes like those worn by their counterparts around the world. As in other historical 
moments, fashion is providing an avenue to assert new feminine identities that reject locally imposed constraints. The link between clothing and young women's emerging sense of their "rights" suggests that in the Pacific, it is political to wake up in the morning and don jeans and a top rather than a meri blouse. Acknowledging the sometimes vexed relationship between fashion and feminism, I argue that the choice to wear certain clothes, typically items that are seen as more popular, new, and arresting - and not others-is not and never has been irrelevant or marginal to the development and expression of feminism in any culture. With this in mind, I turn now to an examination of Stella's aesthetics. This includes analyzing the magazine's depictions of clothing fashions, presentation of cultural objects as accessories, and instances in which the cultural and aesthetic are intertwined, as in fashion design and tattooing.

\section{“YOU DON'T HAVE TO BE A TWO KINA MERI TO WEAR A SINGLET": The Playful Is Political}

During her keynote presentation at the 20I4 State of the Pacific conference in Canberra, Stella editor Amanda Donigi spoke about establishing and editing the magazine (Donigi 20I4). During the question time that followed, an audience member (academic Anthony Regan) told Donigi that Bougainvilleans, like many other Papua New Guineans, objected to women wearing "six-pocket trousers" (ie, cargo pants) on the basis that doing so represented women's incursion into male domains and roles. Donigi's quick response was, "I object to those too." Her witty comeback captures the magazine's playful approach to fashion and the desire of its well-traveled editor to encourage Papua New Guinean women to "think outside of how they currently dress," a desire that was also evident when I spoke with her for this research. "In Papua New Guinea particularly," she said, "we dress down a lot so we don't draw attention to ourselves. I think that's a bit sad because there's so many great fashions out there that we should be tapping into. Having the freedom to wear whatever we want to as well." Coupling the idea that fashion is fun with the message that "women can wear whatever we want to," Stella's representations contrast with the concern and moral judgment that pervades discussions about what women are wearing in PNG. They also constitute an implicit contestation of the Western media's depiction of PNG as a culturally backward place where women appear only as the victims of various forms of violence (intimate partner violence, witch hunts, sorcery). 
For over thirty years, some (usually well traveled or educated) women in PNG have transgressed dress codes (and gender norms) by wearing trousers or-more recently and if they are particularly courageous-jeans. Anthropologist Laura Zimmer-Tamakoshi recalled, for instance: "There were already a few girls who wore Bermuda-like shorts in Yandera village in 1982-83 but [they] were soon hassled into wearing laplaps and skirts. They were girls who had been in towns like Goroka and Hagen and POM [Port Moresby]" (pers comm, 28 Feb 20I4). Zimmer-Tamakoshi's observation that these young women had been "outside" their village is a useful reminder of the link between "exposure" to other ways of seeing and dressing and women's willingness to be more adventurous, even for a time (see also Zimmer Tamakoshi 1993, 1995; Wardlow 2006; Bolton 2003). Nevertheless, within women's home communities, such adventurousness is frequently looked on as evidence of modernity, independence, and sexual promiscuity. Indeed, so linked are these attributes "that one is viewed as evidence of the other" (Macintyre I998, 223). The tok pisin slur "six-pocket meri," which is used to describe women whose inappropriate pants are seen as a sign of sexual license, provides further evidence that some Papua New Guineans continue to interpret the wearing of modern, European-style clothing as a sign of moral depravity. As I and others have noted elsewhere, some educated Papua New Guinean women are choosing to steer clear of marriage altogether or to marry expatriates as a way of avoiding the constraints imposed on them within their families and societies as a consequence of these oppressive interpretations (Spark 20I0, 20I I; Rosi and Zimmer-Tamakoshi I993).

Alongside Cummings (2013 b), other commentators have discussed the apparent threat to the social order posed by women wearing trousers (see Bolton 2003; Wardlow 2006; Pickles 2013). For instance, Nicole Haley commented in relation to the Hela Province of PNG that "women-who are considered to have transgressed local gender codes by wearing shorts or trousers-[have been] stripped, publicly humiliated, and sexually assaulted as punishment" $(2008,35)$. Wearing trousers, interpreted by men as a form of rebellion against male authority and an attempt to usurp this authority, may be considered the most powerful evidence of female transgression. However, deviating from the unofficial uniform of a loose skirt and meri blouse in any way can lead to unwanted attention and harassment.

Some commentators have remarked that the changes in women's clothing are more marked in the "bottom bit" than the "top bit" (Colin Filer, 
pers comm, 4 March 20I4). But most Papua New Guinean women with whom I have spoken mention being scrutinized and told to "tone it down" merely for looking different (Marie, age 25). For instance, Eare (age 30) said when she was living in Goroka, she and her housemates were told "to rethink our clothing choices and that wearing a meri blouse wasn't so bad because it diverts the attention to others who are perhaps wearing more revealing clothes. And mind you, we never wore jeans. I think the closest I came to wearing jeans was loose fitting pants, but even so, this apparently was inappropriate unless we wore big tops or meri blouses to cover our bottoms." "Top" to "bottom," it is very difficult for women to express themselves through their clothing without being judged, ridiculed, and harassed.

Over time, Sue says she "learned" to think through what she could wear and when. "Maybe if I'm going to wear a strappy singlet I have a light cardigan or something that I can wear if I'm actually going out onto the street or something. So you kind of learn, you know." Compared with the situation in which women feel they have to "learn" what they can get away with, Stella's encouragement of women's self-expression through clothing is subversive.

This subversiveness is noticeable throughout the magazine but is perhaps most evident in the fashion spread titled "Second to None" that is a feature of every issue. Donigi described this section when I spoke with her:

We do a page where we do secondhand fashion because that's where everyone buys their clothes from because it's so affordable and there's some really great stuff available. Most people go straight for the T-shirts and the cargo shorts and they're the most expensive things in the shop because they're so popular. You can pick up a really cute summer dress for 30 toea [in PNG currency, Ioo toea $=\mathrm{I}$ kina $(\mathrm{KI})$, which is currently equivalent to about US\$.40]. It's absolutely crazy and we're trying to encourage girls to try dressing up a little more and having some fun with fashion rather than just dressing for practical reasons.... [Stella is] encouraging people to let the blossom come out in a way.

Encouraging women to "let the blossom come out" is deeply countercultural in this context where women are encouraged to be virtuous rather than beautiful and the two characteristics are considered mutually exclusive. While acknowledging the very real risks to women who "let the blossom out," it must be said that such attitudes can only be changed if they are challenged rather than accepted and adhered to. Creating new 
narratives about the meanings of what women wear seems a good place to start, and one way to do this is through the idea that clothes can be fun.

The "Second to None" section in issue ro provides a compelling example of this politics of fun. The caption is "Mash Up" and the page reads: "Mixing and matching your wardrobe is a delicate activity, but the rules were made to be broken, so have a little fun mixing patterns the next time you are feeling inspired. Pattern matching rules: there are no rules-go with your gut" (figure 2; Stella, February-March 20I4, I4-I 5). There is a profound contrast in spirit between the injunction to "go with your gut" and the many rules that Sue and other working Papua New Guinean women feel they must negotiate when deciding what to wear.

The "Second to None" pages in issue 9 are similarly playful. Papua New Guinean women have long been valued for their reproductive work, physical labor, and submissive demeanor. In contrast, issue 9 encourages readers to "Bring the Bling," declaring: "Every girl's wardrobe should harbor at least one sparkly item. Exaggerate your glistening personality with glitter, sequins, sparkles and diamantes" (Stella, January 20I4, I4-I 5). Such positive injunctions to be bold, even if only with one's look, are intrinsically affirming for young, educated women who are regularly told that they are too loud, opinionated, and showy. Joanne (age 25) told me, for example, that her family tells her: "Don't speak out loud, don't be too loud, don't get too much attention cause someone's going to strike out at you or . . . cause guys will harass you if you're just up too loud." Though she dresses as she likes when she travels outside PNG, when she returns to Moresby, Joanne says she "shuts down and clothes up."

Given these injunctions to "tone it down" (Marie, age 25), it is unsurprising that readers appreciate Stella's "Second to None" spread. The following comments are indicative.

I have a couple of favourite sections. The first would have to be the section that features finds at the secondhand stores. This shows that the magazine is in tune with their local readership as "SH" shopping is big in PNG. I love how the finds are pieced together to create a look (Gloria, age 35 ).

They are also promoting what fashion we have and you know, where you can go to get them. It's making women feel like, I can dress up too and look good, it's about self-image and even hairstyles.... I was like "this is so good" (Grace, age 28 ).

And another thing, like women now are starting to try to make themselves look, beautify themselves ... you just flip the page open seeing, you know, 


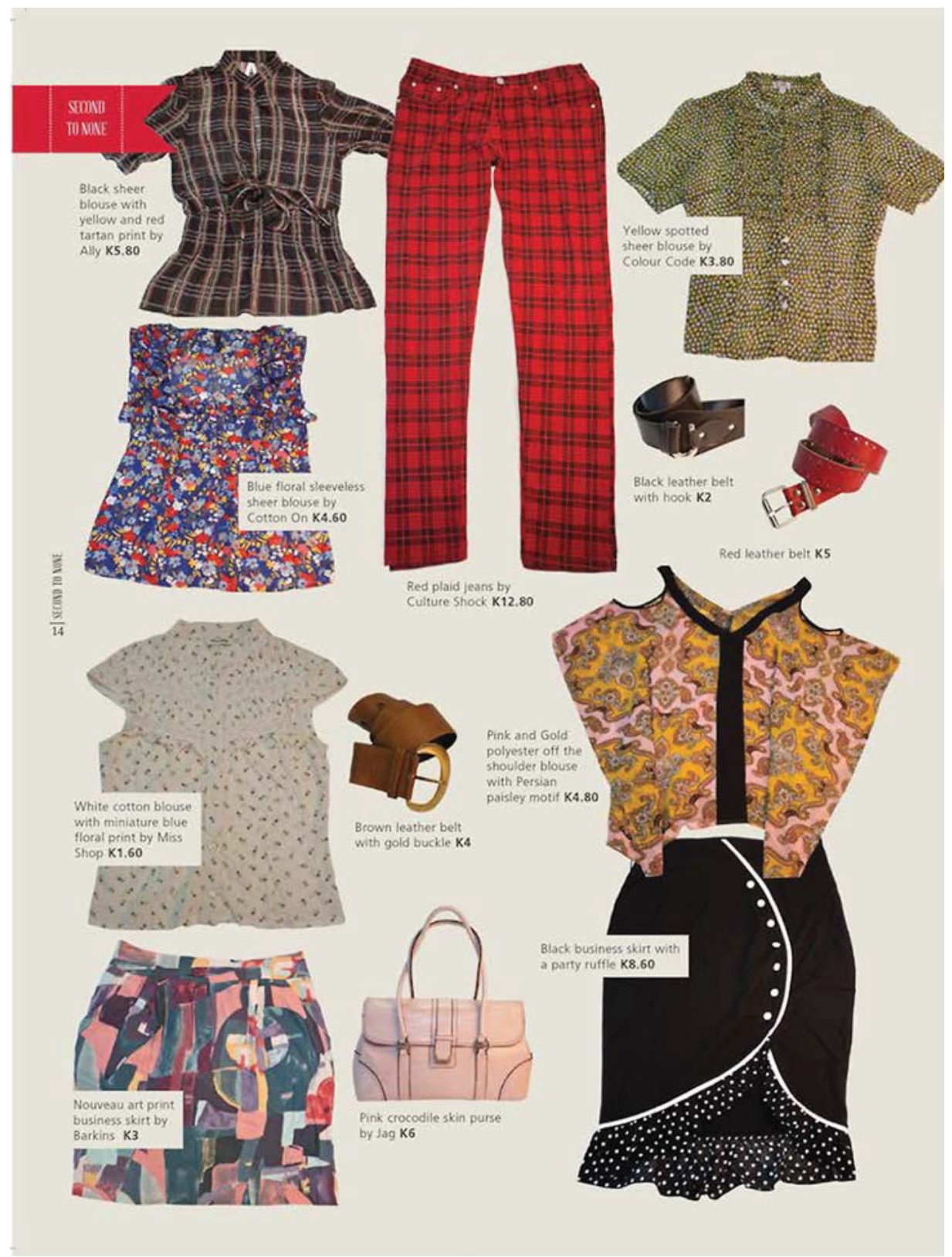

Figure 2 "Second to None." Secondhand fashion, Stella, issue ro (FebruaryMarch 20I4), pages I4-I 5 . 


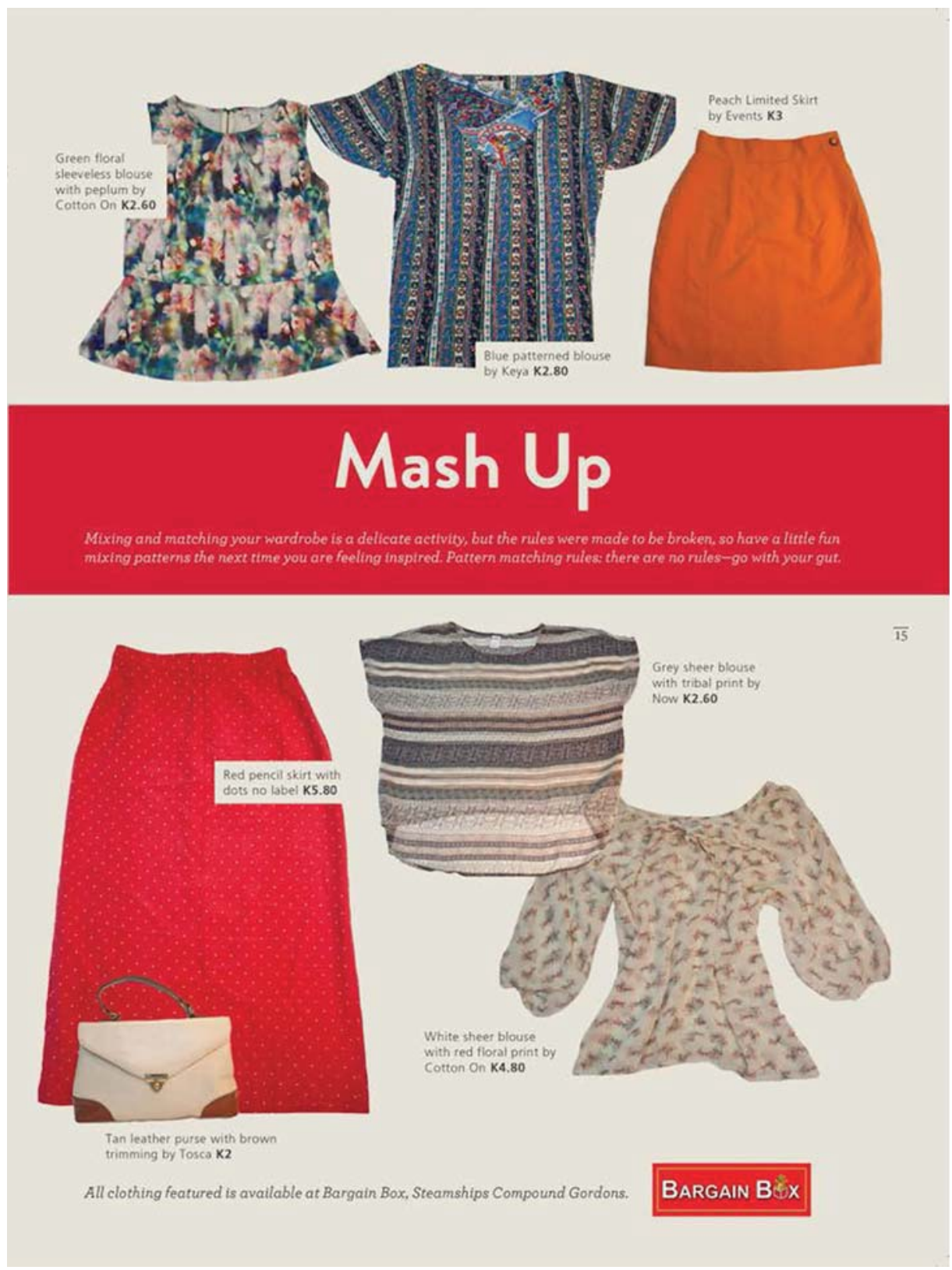


fashion and not only fashion but good, appropriate wear which I consider, for me, personally, like it's good, it makes me feel, “oh, I want to read that. I want to know more about it" (Tiare, age 27).

With a brazenness that could almost be read as naivety were it not for her obvious familiarity with PNG culture and norms, Donigi flouts conventional versions of "good womanhood" to celebrate the modern, the fashionable, and even the showy side of femininity. Although some readers discussed whether Papua New Guinean women could really get away with wearing some of the clothes depicted in the magazine, they seemed overall to perceive Stella as extending the boundaries of what it was possible for women to wear. As Grace commented: "the more we see this maybe the more we get, like ... 'normalised' and say 'this is fine." Her comment reveals the importance of exposing audiences in PNG to a range of images of women. Undermining the link between Western-style clothes and promiscuity, Stella's images remind readers that “you don't have to be a two kina meri to wear a singlet" (Eare, age 30 ). In a context in which women are constantly scrutinized in relation to their appearance, Stella creates a community in which young women's preferences are normalized and celebrated as "progressive" (Eare) rather than problematic.

\section{New TaKe On The Old?}

Arguably, a crucial characteristic of modernity is a reengagement with and reframing of "tradition" (Thomas, Cole, and Douglas 2005). Such strategic reframing is perhaps particularly important for urban, educated Papua New Guinean women, many of whom are unwilling to accept uncritical interpretations of "custom," particularly those "customs" that seek to limit women's choices and behavior or to "legitimate" gender-based violence. It is also educated women who are most likely to be construed as culturally "inauthentic" (Spark 20II). As other commentators have noted, this charge of inauthenticity is a convenient way to dismiss these women as betrayers of culture and thus to marginalize their voices and perspectives (see, eg, Zimmer-Tamakoshi I993; Jolly I992, 2005). Somewhat paradoxically, however, it is precisely women in this cohort, including many who are internationally educated, are widely traveled, or work in international organizations, who are most likely to express the desire to learn about and celebrate Papua New Guinean cultures. Unwilling to relinquish their cultural distinctiveness in favor of what is construed to be 
an undifferentiated global "culture," they actively seek new ways to connect with and learn about cultural traditions, both their own and others. As Ton Otto has noted, this contemporary concept of cultural heritage "emphasises the idea of 'ethnic connections' [and represents] an awareness of heritage as not only a matter of difference and competition but also of making connections between people with different traditions" (Otto 2015). Through its representations of culture as something worth "having," Stella finds another way to speak precisely to educated modern women. Representing and promoting cultural pride, the magazine's aesthetics are a key marker of a modern politics of identity rooted in invocations of the traditional.

The magazine celebrates Pacific cultures in several ways. Since its first issue, Stella has reframed locally made products and fashions. For instance, the first issue features a double-page spread titled "the groove." The spread shows "kunai grass wrapping paper" and a "Manus basket" as well as casual shoes by local designer, Bobby Weber (figure 3). In a similar vein, the fashion page profiles Nelly Joku Moi-He, a woman of mixed West Papuan and Papua New Guinean descent who established "Village Exotics," a company that produces "eco-friendly, stylish affordable accessories." Stella's focus on promoting local products and fashions continues in issue 2 with promotions of "shell-bling from the islands," purses made of pandanus leaves, and padded pot bags with PNG flags (figure 4). Like so many other textual and pictorial moments in Stella, these examples mark the magazine's Pacific origins and perspective, encapsulating its breezy blending of the global and the local, the traditional and the modern. However, while Western magazines represent "tribal" or "traditional" aesthetics as exotic augmentations of current trends, Stella's depiction of traditional Pacific cultures is more than aesthetic. As the interviews with readers reveal, such moments engender cultural pride.

Bernadette, a 25-year-old honors student at the University of Goroka in the Eastern Highlands Province of PNG, had read issues I and 2 of Stella when I interviewed her for this research. She commented that she really liked seeing the "Pacific type of jewelry and hand bags made from local stuff" because "it makes you think about what you are and what you have." Remarking that the photography in Stella encouraged her to see things differently, she said: "It's something about pictures, ah? Like how photography makes everything look nice and a basket you'd always carry around, or a bamboo comb on your hair but when it's in a magazine it looks really good." Confirming the magazine's reframing and revalu- 

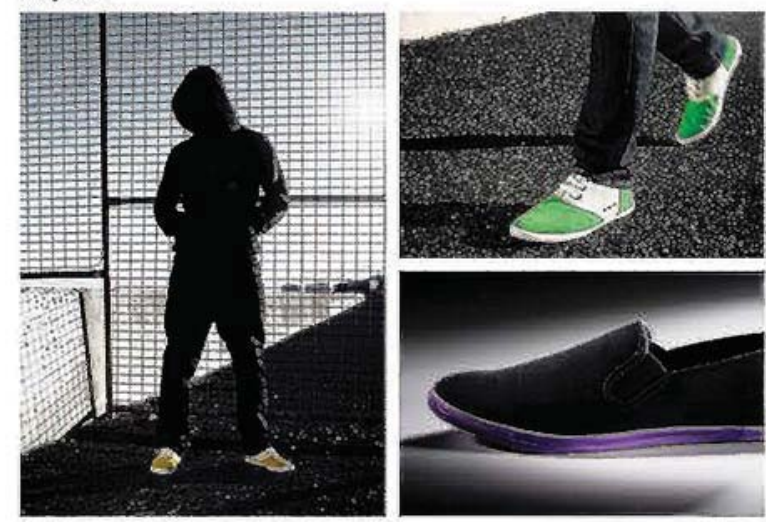

\section{BOBBYWEBER}

Gel some colour in your sole by slipping into the fresh design of these bobbyweber kicks. They come in two styles: Mr Vu and Thot's Rod. And whot's more, these ore designed by New Irelonder Bobby Whober. We've got tive poirs lo give dwoy, to win. emait us of helloe stefiomog.com and tell us whot puts colour in your sout. The best five enswers wolk owoy in styla!

www.bobbyweber.com

(Mr Vu K50.00. That's Aod K100.00)

KUNAI GRASS WRAPPING PAPER

So you've found the pertect birthdoy present. but now you howe to wrop it... Don'l poss up the opporiunity to go eco.friendly with this kunei gross wropping paper for double the impoci on t5 your gith giving. It's the first of its kind in Popuo New Guineo and hopefully an toec thot witl spread the wildire. Brovo.

(Available trom Clly Pharmocy K3.00)

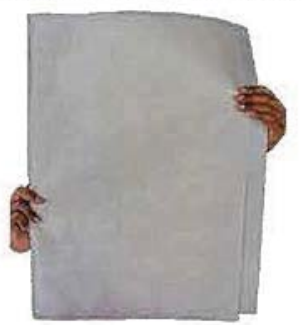

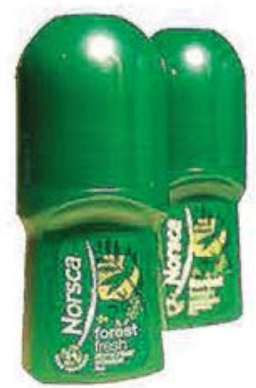

\section{NORSCA}

II you've tried a variely of ontiperspiront deodorents and just con't find the right protection, then I's time to wake up and smell lise the forest. Norsco's Fores! Fresh gives you 24 hour protection that won't let you down. Good bye to crowas moving oway trom you, elbows tucked tirmly into your woist. and agonising personal discomtort. Confidence now comes in the form of a convenient green roll-on. (Avatoble from Chemcore K9.50)

PAINIM T SHIRT

Painim $T$ shirt is a smoll internet $T$ Shirt shop promolting love and care in Popua New Guinea. Inspired by current high ievels of viofence, espociolly towards wornen, the T-shirts spregd positive messoges of peoce, respect and tove, with bright and hoppy designs. All proceeds go to helping PNG Chorities. We ore giving away one of these cule $T$ shirts to 5 lucky reodiers. To win simply emoil us of helloo stellomog.com telling us how you spreced peoce, respect, and tove. for more informotion contoct: Lito Lokotokog yohoa.com and vist sites.google.com/stte/poinimishirthome

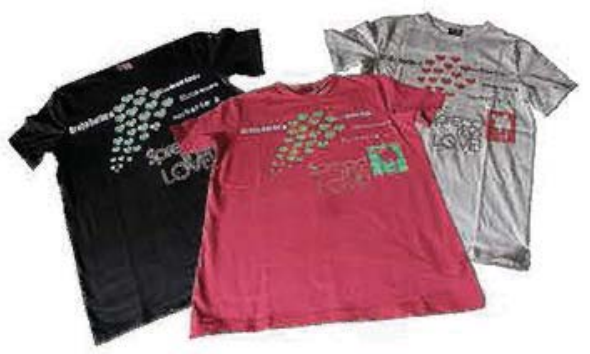

Figure 3 “The Groove," Stella, issue I (August-September 201 2), pages 6-7. 


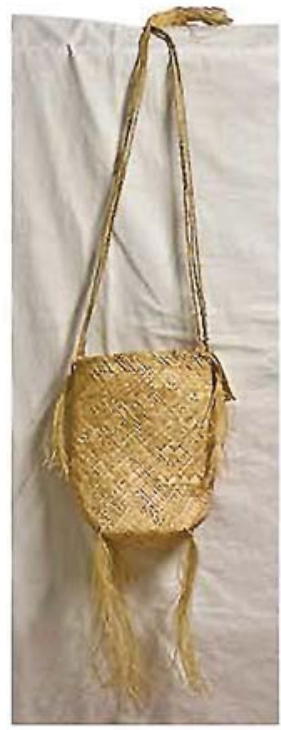

\section{GAMBA KRAI ART}

You might hove cought sight of the bright colours radiating trom below the traveltator at Vision City. Port Moresby in the post couple of months. But if you've had a closes look you'll know there's a snug ittle ort gallery/studio/shop lucked owoy that stocks contemporary and troditional pointings, bilums, baskets, carvings..., you name III We think their delicole white baskets from Manus are cuilurally and teshionably splendid.

(Monus Bosket K:00.00)

\section{TATTLY}

Being cool $24 / 7$ is hard work, tiresorne, and sometimes even pointuli, if you want to try out "coer" tempocarily test out these revolutionary temporany tottoos from Taltly. Vibrant, quaint, individual, and more importantly. Ihey ship world wide. Shop onine through wwwtallty.com -
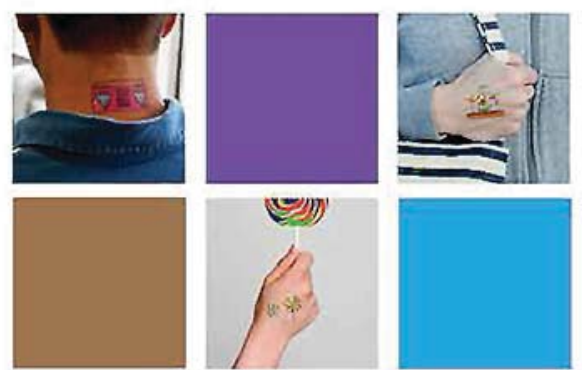

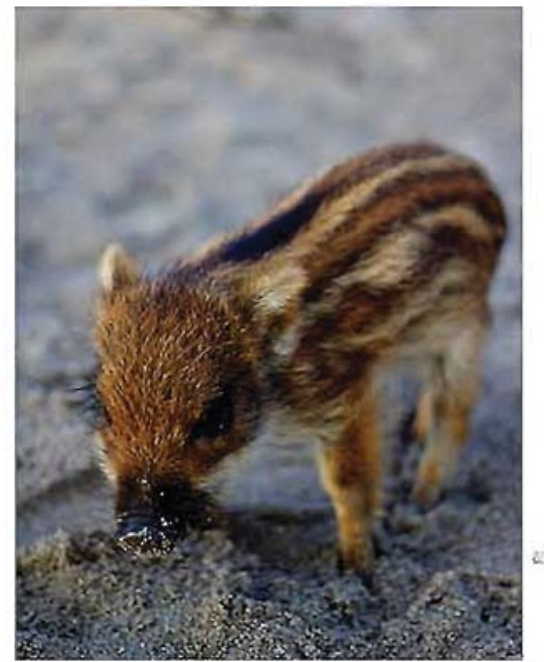

\section{A PIGGY PROFILE}

Our fittle pig friends cre very intelingent. They will pick up tricks toster than dogs. Atter chimpanzees, dotphins and elephants, pigs rank 4 th in animal intelligence. Pigiets will learn and respond to their names at just two to three weeks of age.

"Act like o pig" - Whors Pigs are very sociol. They onjoy affection ond form close bonds with eoch other and other species. When resting, they will snuggle. And they tike to tek (grunt) to one another constantly.

Live like o pig' - II's not soll - Pigs are very clean. They toilet lor from their living and eoling areos. And even nowbors piglets just a few hours otd will loave the nest 10 relieve themselves.

Sweat tike a pig" - FALSE - Pigs oon't sweoll That is why they cool down by rolling in mud. The mud also cats as a sun-block and armour against insects. Although, it given the chance, pigs preter woter to mud and ore grea! swimmers! 


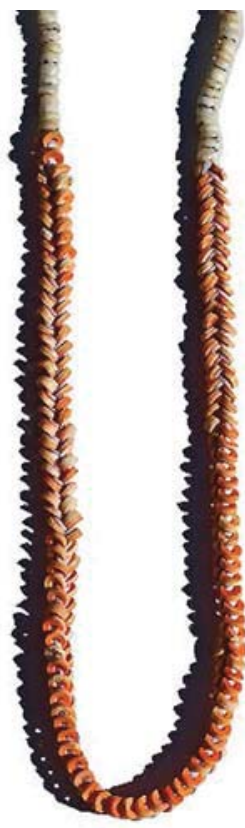

SHELL-BLING FROM THE ISLANDS

Weive all seen or bought o version of the well-known shell neckloces from the Solomon Islands by now. But all good things must come to an upgrade, and this new-style jewellery is what we're shelling out for this issuel Necklaces K50. Bracelets K2O. Eorrings K2O, or K80 for a full set.

Look for Mwekou Kowatolu of the Elo Beach Monthly Morkets.

RAINBOW B[W]RITE Why are there so many songs about rainbows. and not more pencils that collectively make

rainbows? Firstly pencils are owesome. They are more useful than pens when you're travelling through space in rockets, and are modelled after the "stylus" an ancient writing instrument that used to write on "papyrus", the ancestor of paper. Secondly, bright colours just moke for a happy day and probably better quality writing. UBL Bend and Twist 5 pock of pencits avoilable from Star News Link Vision City K 4.50

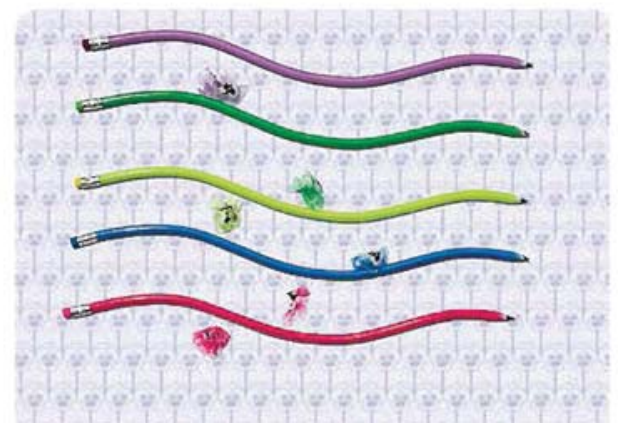

Figure 4 "The Groove." Stella, issue 2 (October-November 20I 2), pages IO-II. 


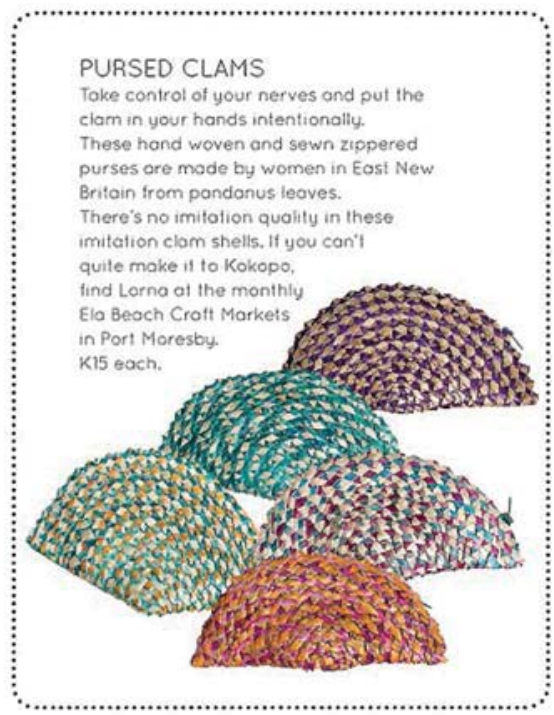

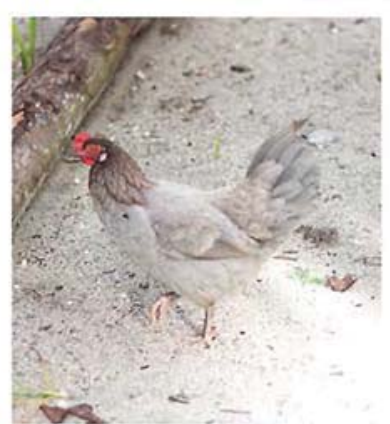

CHECK OUT CHICKENS

Although chickens ore the closest living relatives to the f-rex, don't ossume thot they are callous animals! in fact, they are very social animols. A mother hen bonds with her chicks before they hatch. She cares for and clucks to her unborn chicks. turning them in the nest as they chirp back to her and to one another. They mourn the loss of a loved one and they will fight to protect their fomily They ensure a consistent dynamic within their flock-society by always filling the rooster role, with a hen if need bet She

will stop loying and begin to crow. If able to dodge o dinner plote destiny. o chicken con live up to 20 years.

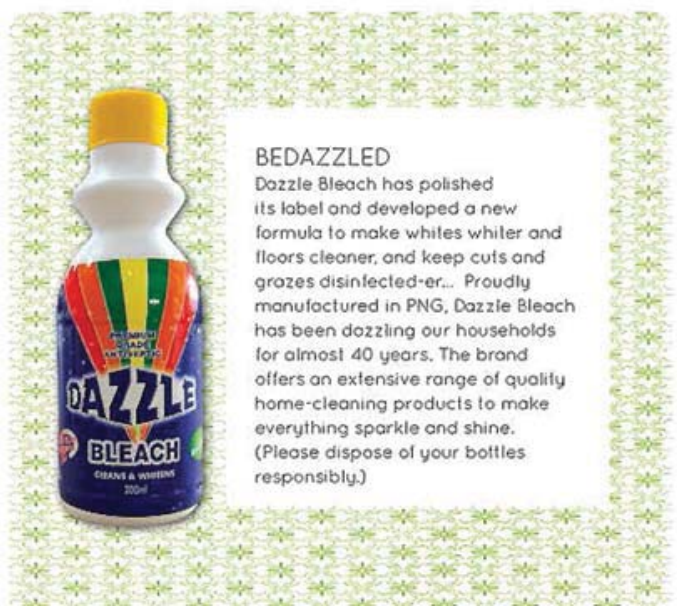


ing of the quotidian and local as fashionable and desirable, Bernadette's response highlights the positive reinterpretation allowed by Stella's representation of local products within the frame of global consumerism. For Bernadette, it was important that the desirable objects were "not just overseas-made jewelry but traditional made jewelry with coconut shells and bilums with the coconuts on the side." Moreover, her enjoyment of the reframing and aestheticization of local accessories- "it makes you think about what you are and what you have"-is linked to the experience of cultural pride.

The revaluing of local products and designs within the context of global fashion is also evident in issue 9, which contains information and articles about the inaugural Port Moresby Fashion Festival, held in December 20I3. Donigi played a central role in organizing this event and made it a focus of the ninth issue of Stella. The large photo spreads in this issue feature models wearing the clothes of local Papua New Guinean designer Sarah Todd, whose indigenous-patterned designs also adorn the models on the striking cover (figure 5).

While the cover photograph has "universal" qualities—a beautiful, pristine setting and characteristically long-legged models-the most prominent of the three models is wearing a red cape dress with an obviously indigenous pattern. Describing her label, PNGian Kala (pronounced "Papua New Guinean color") in the interview she did with Donigi, Todd said: "PNGian Kala is a brand that I've laboured over to put the diversity, the beauty, and the colours of our culture on prints. I want to slowly go away from importing from America ... but still have affordable clothing so people can walk in and buy something for KI5 with PNGian Kala on it; we have printed bilums, traditional tattoos, Oro tapa and lime pots so far. All these objects have meaning." In the move to insert PNG into the global world of fashion, it is precisely the local and traditional that is given "meaning." And this meaning matters to the women who make up Stella's audience. Like Todd's desire to shift from importing American clothing to selling more clothes that reflect "the diversity, the beauty, the colours of our culture," these women are quintessentially modern. Sufficiently removed from "traditional" Papua New Guinean society by education and employment, it is they who are best placed to re-value the traditional within this new global, capitalist schema. Embodying a distance from PNG's "traditional" past in a way that their rural subsistencebased counterparts do not, the modern educated working women who read Stella respond to its representations of the local and traditional. 


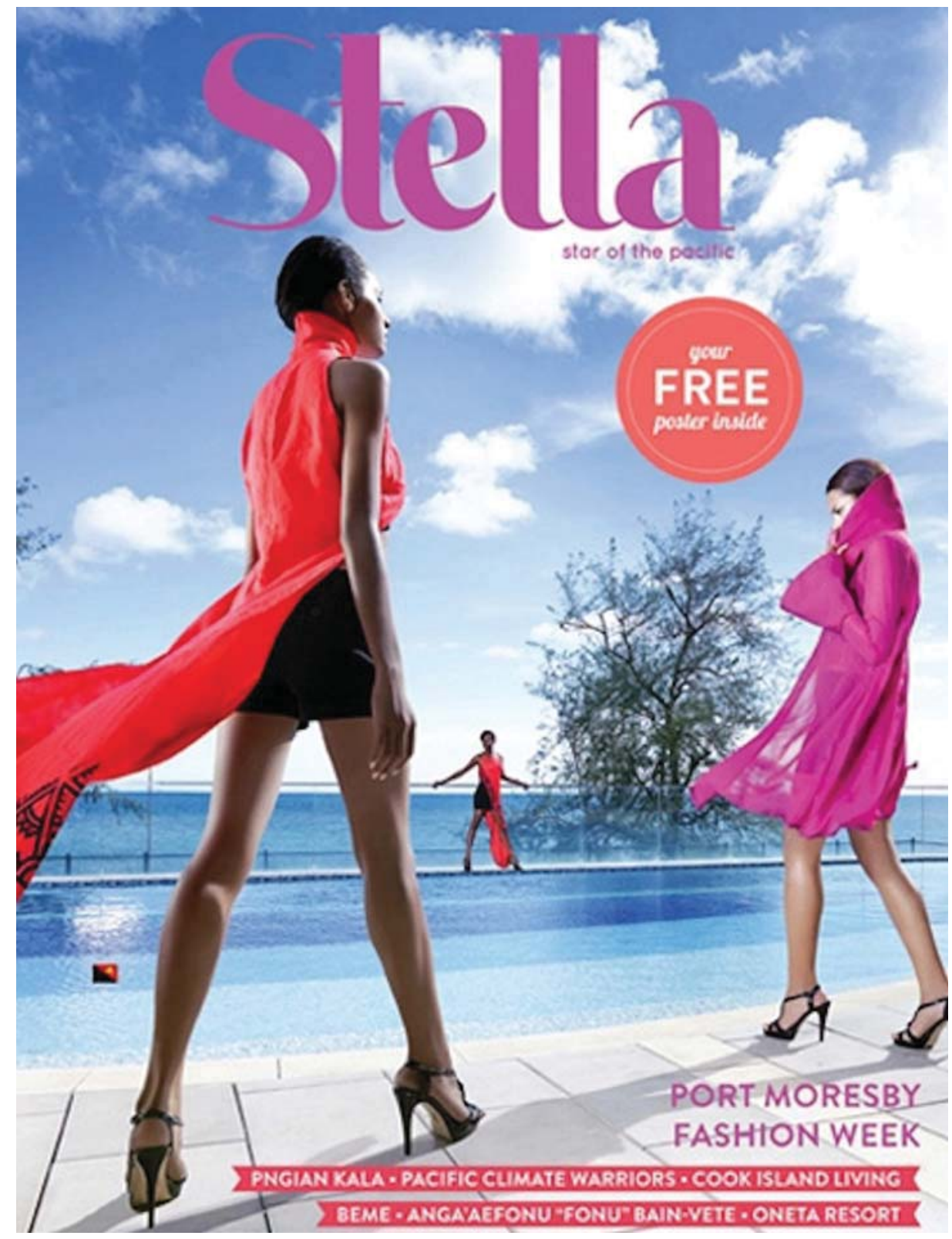

Figure 5 Cover photo, Stella, issue 9 (January 20I4). 
The following extract from my interview with Pauline Vetuna, a Melbourne-based blogger from PNG's Tolai region, demonstrates that readers appreciate this modern-traditional blending and see it as constituting a key aspect of Stella's address and aesthetics:

One thing I did also notice with Stella ... is that there is a blending of old and new that is occurring as well. It's not a complete rejection of "the old," or of traditional ways of seeing or being in the world. Instead there is this kind of marrying of old and new that is occurring. ... And I like seeing that reflected, because I think that is important to sort of maintain a connection with the positive aspects of traditional culture and our roots, even as we progress and become increasingly connected to a globalised culture.

Vetuna's perspective was echoed by Dorothy (age 33), who said she was "interested in women artists of Papua New Guinea especially in the provinces, eg, painters, clay pot makers, grass skirt makers, fashion designers, bilum etc" and Francisca (age 22), who said that Stella's willingness to represent Papua New Guinean culture was "educational, inspiring and motivational at the same time." Francisca saw "other magazines" promoting "western cultures and the products of western, European cultures" and said "it sometimes drives us, Papua New Guineans crazy, you know we forget all about our identity and we want to be like others."

Reader interest in contemporary Pacific peoples' connections to their heritage was also evident in their response to other culture-focused articles in Stella. For instance, when I asked Tiare (age 27) whether there were any particular articles she liked, she mentioned Nigel Harris's article in issue 3 about tattooing and the ways in which tattoos enabled him to connect with his Papua New Guinean heritage. The article, titled "Getting Ink Done," encapsulates the perspective of a diasporic Papua New Guinean. Harris wrote:

I'm mixed (ie, mixed heritage), but I was raised in a string of international schools and eventually Australia, so really I'm much more "white" than I'd like to be. But I've always loved Papua New Guinean designs and I know my roots and I know where I'm from. . . . Seeing indigenous designs from the past play a part in today's pop culture is honestly refreshing. It shows that even as our culture slowly fades, as other knowledge and traditions fail to be passed on, our culture adapts and endures, and we'll never really be able to forget where we come from. (Stella, December 20I2-January 20I3, 25)

The idea of change and adaption lies at the heart of Harris's concept of "culture." Like the other representations of cultural heritage in Stella, it 
thus resembles what Ton Otto has identified as kalsa rather than kastam (20I4). For Tiare, Stella's willingness to include articles such as this one was a sign that the magazine was interested in exploring "cultural values" alongside standard women's magazine components such as information about beauty products or cooking. Other articles in Stella on the subject of tattooing (issues 3 and ro) also highlight the importance of the practice for diasporic Papua New Guineans in Australia, an under-researched group who form an important audience for the magazine and also serve as a source for contributions.

Because educated Papua New Guinean women's desire to learn about cultural traditions frequently coexists with a rejection or critique of local customs, there is considerable appeal in Stella's examination of cultural traditions as these are expressed "aesthetically," through tattooing or fashion design, for example. By engaging with the magazine's explorations of these less contentious and more benign aspects of "culture," PNG's modern women can embrace the aesthetics of tradition while rejecting customs such as braid prais (bride price) that many perceive to be outdated and oppressive. This strategic and selective interest in and adoption of indigenous "cultural heritage" is a hallmark of modern indigenous identity, particularly among those who construct "heritage" through reference to more inclusive, changing concepts of "culture" as opposed to kastam (see Otto 20I4; Otto and Thomas 1997). Pitching itself to the educated cohort most likely to empathize with the construction of contemporary feminine Pacific subjectivity as something that exists in the interstices between tradition and modernity, Stella implicitly queries long-established but dubious constructions of "authentic" and "good" women in PNG. Importantly, it also gives women the chance to define their own femininity and to incorporate notions of fun into these definitions. There is nothing frivolous about presenting this message in this context, however glossy and attractive the package in which it is wrapped.

\section{Conclusion}

In August 20I2, I was pleasantly surprised to see Jennifer Baing-Waiko gracing the front cover of the first issue that year. Already, Stella is beginning to render such representations more familiar in PNG. In 20I2, another women's magazine, Lily, was launched in Port Moresby. Targeting a somewhat overlapping readership and featuring articles about many of the same professional and business women that are featured in Stella, 
the release of Lily suggests a certain confidence that Papua New Guinean women constitute an important market, albeit one that has been virtually overlooked until now. Complicating the politics of aesthetics and beauty and indeed of what constitutes "culture," Stella smuggles an inherently and deeply political message between its glossy pages. In this process, Donigi's witty comebacks and claims to be steering clear of "the mire of PNG politics" (Chandler 20I3) appear to be furthering rather than undermining the impressive job she is doing of changing things.

In the I970s, the women's magazine Cleo spoke to the women of Australia in a new way, reflecting and heralding societal changes in attitudes toward gender roles (La Masurier 2009, 20II). In the present era and at a time of great change in PNG, Stella speaks to and honors women whose identities and desires have been marginalized in this context. By doing so, the magazine and its editor are playing a significant role in the creation of an emergent subculture in PNG.

As I write, Donigi is finalizing the arrangements for "Runway 20I4," a second fashion event in Port Moresby designed to celebrate Stella's second birthday (figure 6 appears on pages 65-66). The advertisement for Runway states that it "will showcase Ioo looks from ro fashion designers from around the Pacific." Moreover, the money raised from graffiti art done as part of the festival will be donated to the "Port Moresby Business \& Professional Women's Association who will establish a new fund for young women in arts and fashion." Donigi's role in organizing such events and her ability to generate further outcomes specifically benefiting young women demonstrate her commitment to promoting versions of femininity hitherto marginalized in PNG. Her interventions also reveal the relationship between these representations and material change in the lives of women. Though it is often conceived as frivolous, the world of fashion in PNG is a focal point of change for young women. The new representations in Stella mean that rather than being dismissed as part of an inauthentic minority of women who have forsaken their culture, young women are more likely to be seen as the "movers and shakers" of the region. Moreover, in this role, they, like Donigi, have increased potential to open up new ways of connecting with culture that generate social and economic development in PNG and the region.

I would like to thank Amanda Donigi, Pauline Vetuna, and all of the Papua New Guinean women who have spoken with me for this research. Thanks also 

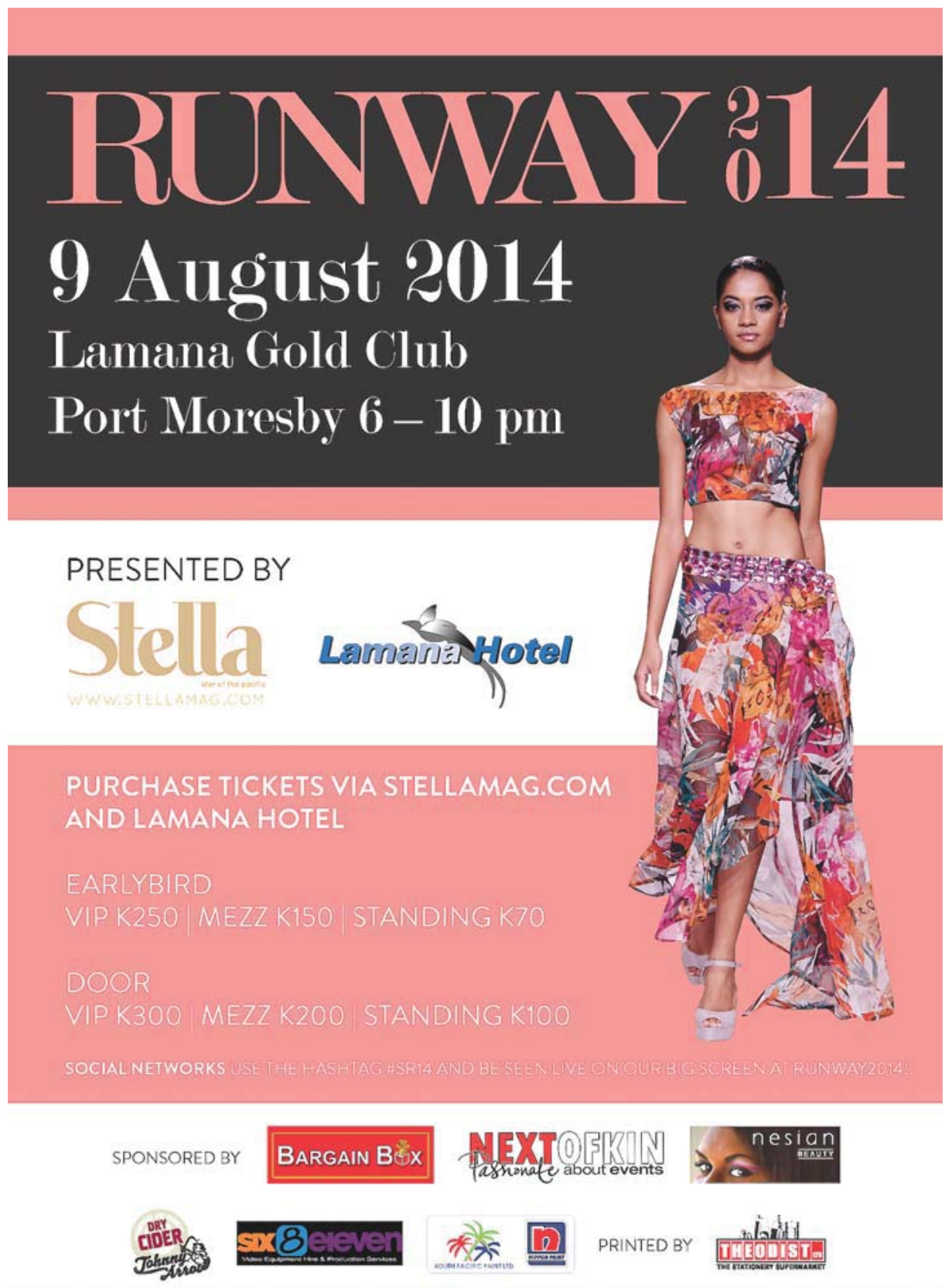

FIgURE 6 Advertisements for Runway 20I4, sent to author by Amanda Donigi, August 20I4. 

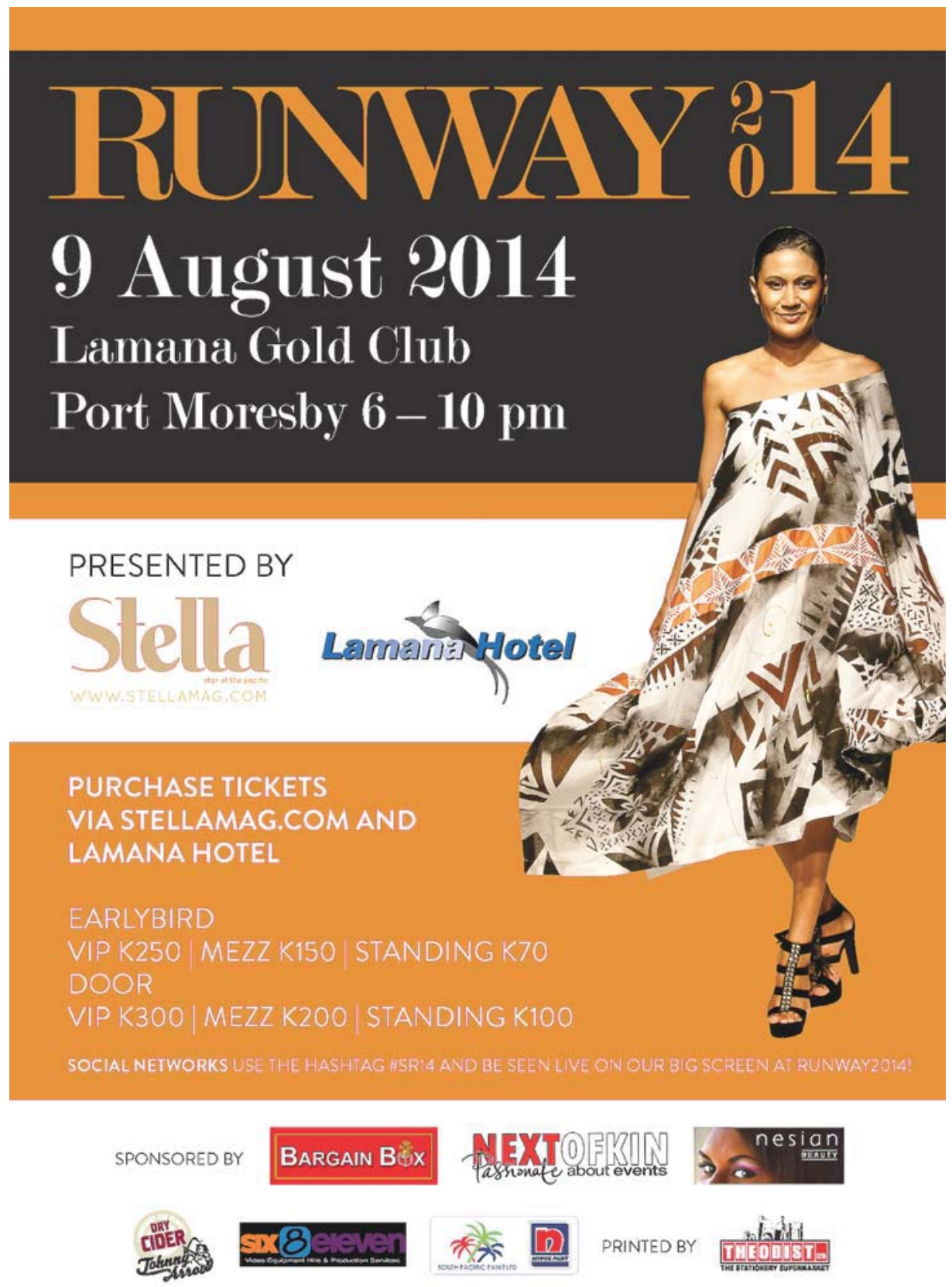
to Theresa Meki for her support with the interviews in Goroka. Amanda Donigi gave her permission to reprint pictures from Stella. Without them, the article would not be the same and I am grateful for her generosity. Thank you also to the external reviewers for supportive and helpful feedback on an earlier version of the article.

\section{References}

Addo, Ping-Ann

2009 God's Kingdom in Auckland: Tongan Christian Dress and the Expression of Duty. In Colchester 2003, I4 I-I63.

Bolton, Lissant

2003 Gender, Status and Introduced Clothing in Vanuatu. In Colchester 2003, II9-I 40.

Brown, Paula

I988 Gender and Social Change: New Forms of Independence for Simbu Women. Oceania 59 (2): I23-I4I.

Budgeon, Shelley, and Dawn H Currie

I995 From Feminism to Postfeminism: Women's Liberation in Fashion Magazines. Women's Studies International Forum I 8 (2): I73-I 86.

Chandler, Jo

2013 For Those Who've Come across the Seas: A Short Trip to PNG. The Global Mail, 24 July.

Colchester, Chloe

2003 a Introduction. In Colchester 2003, I-24.

$2003 \mathrm{~b}$ T-shirts, Translation and Humour: On the Nature of Wearer-Perceiver Relationships in South Auckland. In Colchester 2003, I67I92.

Colchester, Chloe, editor

2003 Clothing the Pacific. Oxford. New York: Berg.

Cummings, Maggie

2008 The Trouble with Trousers. In Making Sense of AIDS: Culture, Sexuality and Power in Melanesia, edited by Richard Eves and Leslie Butt, I33-I 49. Honolulu: University of Hawai'i Press.

20I3a Imagining Transnational Futures in Vanuatu. In A Companion to Diaspora and Transnationalism, edited by Ato Quayson and Girish Daswani, 38 I-396. Oxford: Blackwell Publishing Limited.

20I3b Looking Good: Island Dress in Vanuatu. The Contemporary Pacific 25:33-65.

Donigi, Amanda

20 I 4 Keynote address, State of the Pacific Conference, Australian National University, Canberra, I 8-I9 June. Podcast. http://ips.cap.anu.edu.au/ 
news-events/podcasts/state-pacific-20I 4-keynote-address-amanda -donigi [accessed 25 Sept 20I4]

Duits, L, and L van Zoonen

2006 Headscarves and Porno-Chic: Disciplining Girls' Bodies in the European Multicultural Society. European Journal of Women's Studies I 3

(2): IO3-II7.

Gewertz Deborah B, and Frederick K Errington

I999 Emerging Class in Papua New Guinea: The Telling of Difference. Cambridge, uk: Cambridge University Press.

Gill, Rosalind

2007 Critical Respect: The Difficulties and Dilemmas of Agency and "Choice" for Feminism: A Reply to Duits and van Zoonen. EuroHaley, Nicole pean Journal of Women's Studies I 4 (I): 69-80.

2008 When There's No Accessing Basic Health Care: Local Politics and Responses to Hiv/Aids at Lake Kopiago, Papua New Guinea. In Making Sense of AIDS: Culture, Sexuality and Power in Melanesia, edited by Richard Eves and Leslie Butt, 24-40. Honolulu: University of Hawai'i Press.

Jacobsen, Lisa

2010 Fashion, Feminism, and the Pleasures and Perils of Consumer FanJolly, Margaret tasy. Journal of Women's History 22 (I): I78-I 87.

I992 Specters of Inauthenticity. The Contemporary Pacific 4:49-72.

2005 Beyond the Horizon? Nationalisms, Feminisms, and Globalization in the Pacific. Ethnohistory 52 (I): I37-I 66.

Le Masurier, Megan

2009 Desiring the (Popular Feminist) Reader: Letters to Cleo during the Second Wave. Media International Australia I3 I (May): Io6-I I6.

20I I Reading the Flesh. Feminist Media Studies I I (2): 2 I 5-229.

Linnekin, Jocelyn

2004 Epilogue: Is "Cultural Identity" an Anachronism in a Transnational World? In Shifting Images of Identity in the Pacific, edited by Toon

Macintyre, Martha van Meijl and Jelle Miedema, 237-256. Leiden: KITLV.

I998 The Persistence of Inequality: Women in Papua New Guinea since Independence. In Modern Papua New Guinea, edited by Laura Zimmer-Tamakoshi, 2I I-23I. Kirksville, mo: Thomas Jefferson University Press.

2000 Hear Us, Women of Papua New Guinea: Melanesian Women and Human Rights. In Human Rights and Gender Politics: Perspectives on the Asia-Pacific Region, edited by Anne-Marie Hilsdon, Vera 
Mackie, Martha Macintyre, and Mila Stivens, I47-I7I. New York: Routledge.

Otto, Ton

20I5 Transformations of Cultural Heritage in Melanesia: From Kastam to Kalsa. International Journal of Heritage Studies 2I (2): II7-I 32.

Otto, Ton, and Nicholas Thomas, editors

I997 Narratives of Nation in the South Pacific. Amsterdam: Harwood Academic.

Pickles, Anthony

2013 Pocket Calculator: A Humdrum “Obviator” in Papua New Guinea? Journal of the Royal Anthropological Institute I9 (3): 510-526.

Quayson, Ato, and Girish Daswani, editors

2013 A Companion to Diaspora and Transnationalism. Oxford: Blackwell Publishing Limited.

Roberts, Mary Louise

2008 Making the Modern Girl French: From New Woman to Eclaireuse. In Weinbaum and others 2008, 77-95.

Rosi, Pamela, and Laura Zimmer-Tamakoshi

I993 Love and Marriage among the Educated Elite in Port Moresby. In The Business of Marriage: Transformations in Oceanic Matrimony, edited by Richard Marksbury, I75-204. ASAO Monograph I4. Pittsburgh: University of Pittsburgh Press.

Spark, Ceridwen

20I0 Changing Lives: Understanding the Barriers that Confront Educated Women in Papua New Guinea. Australian Feminist Studies 25 (63): I7-30.

20I I Gender Trouble in Town: Educated Women Eluding Male Domination, Gender Violence and Marriage in PNG. The Asia Pacific Journal of Anthropology I2 (2): I 64-I 80.

20I4a An Oceanic Revolution? Stella and the Construction of New Femininities in Papua New Guinea and the Pacific. The Australian Journal of Anthropology 25 (I): 54-72.

20I4b "We Only Get the Daylight Hours": Gender, Fear and "Freedom" in Urban Papua New Guinea. Security Challenges Io (2): I 5-3 I.

Stella magazine. http://www.stellamag.com

Thomas, Nicholas, Anna Cole, and Bronwen Douglas, editors

2005 Tattoo: Bodies, Art, and Exchange in the Pacific and the West. Durham, NC: Duke University Press.

van Meijl, Toon

2004 Introduction. In Shifting Images of Identity in the Pacific, edited by Toon van Meijl and Jelle Miedema, I-20. Leiden: KITLV. 
Wardlow, Holly

2005 Transformations of desire: envy and resentment among the Huli of Papua New Guinea. In The Making of Global and Local Modernities in Melanesia: Humiliation, Transformation and the Nature of Cultural Change, edited by Joel Robbins and Holly Wardlow, 57-7I. Aldershot, UK: Ashgate.

2006 Wayward Women: Sexuality and Agency among the Huli. Berkeley: University of California Press.

Weinbaum, Alys Eve, Lynn M Thomas, Priti Ramamurthy, Uta G Poiger, Madeleine Yue Dong, and Tani E Barlow, editors

2008 The Modern Girl Around the World: Consumption, Modernity, and Globalization. Durham, NC: Duke University Press.

Zimmer-Tamakoshi, Laura

I993 Nationalism and Sexuality in Papua New Guinea. Pacific Studies I6 (4): 6I-97.

I995 Passion, Poetry, and Cultural Politics in the South Pacific. Ethnology 34 (2): II3-I 27.

I997 Wild Pigs and Dog Men: Rape and Domestic Violence as Women's Issues in Papua New Guinea. In Gender in Cross-Cultural Perspective, edited by Caroline B Brettell and Carolyn F Sargent, 538-553. New York: Prentice Hall.

\section{Abstract}

In this article I discuss Stella, a new women's magazine in Papua New Guinea. Noting that Stella provides a context for celebrating new Pacific femininities, I argue that the magazine's representations of fashion are a crucial way in which this refiguring of the feminine occurs. Discussing the significance of what women wear through reference to anthropological insights about the relationship between clothing, gender, and status, I suggest that in PNG, clothing is a focal point of cultural debate. Through its playful politics, Stella intervenes in this debate, thus smuggling a deeply political message between its glossy pages. In addition, I demonstrate that through its selective aestheticization of the "local" and the "traditional," the magazine acknowledges educated, young Papua New Guinean women's desire to reconfigure "culture" in more inclusive ways.

KEYWORDs: Papua New Guinea, gender, fashion, feminism, culture, media 